\title{
Maturational changes in connexin 43 expression in the seminiferous tubules may depend on thyroid hormone action
}

Katarzyna Marchlewska', Krzysztof Kula², Renata Walczak-Jedrzejowska², Wojciech Kula , Elzbieta Oszukowska², Eliza Filipiak¹, Tomasz Moszura, Jolanta Slowikowska-Hilczer ${ }^{1}$

'Department of Reproductive Endocrinology, Medical University of Lodz, Poland 2Department of Andrology, Medical University of Lodz, Poland

${ }^{3}$ Chair of Clinical and Experimental Physiology, Medical University of Lodz, Poland ${ }^{4}$ Department of Cardiology, Polish Mother's Memorial Hospital, Lodz, Poland

\author{
Submitted: 11 August 2010 \\ Accepted: 2 May 2011
}

Arch Med Sci 2013; 9, 1: 139-145

DOI: 10.5114/aoms.2013.33074

Copyright $\odot 2013$ Termedia \& Banach

\section{Abstract}

Introduction: Connexin 43 (Cx43) mediates the effect of thyroid hormone on Sertoli cell maturation in vitro. We investigated the influence of triiodothyronine (T3) administration on Cx43 expression in relation to the progress in seminiferous tubule maturation.

Material and methods: Male rats were daily injected with $100 \mu \mathrm{g} \mathrm{T3/kg} \mathrm{body}$ weight from birth until postnatal day (pnd) 5 (transient treatment - tT3) or until pnd 15 (continuous treatment - CT3) or solvent - control (C). On pnd 16 serum hormone levels, body and testes weight, seminiferous tubule morphometry, Cx43 immunostaining and germ cell degeneration were investigated. Cx43 expression was also assessed in six 50-day-old adult untreated rats.

Result: tT3 increased 2.6-fold serum level of T3, testes weight, and seminiferous tubule diameter, and induced maturation-like dislocation of Cx43 expression from the apical to the peripheral region of Sertoli cell cytoplasm. In addition, incidence of Cx43-positive tubules declined from $86 \%$ in C to $46 \%$ after tT3, being similar to the adult value (30\% of tubules Cx43-positive). In turn, cT3 increased serum T3 level 12-fold, and decreased body weight. Seminiferous tubules became shortened and distended, Sertoli cell cytoplasm vacuolated, Cx43 expression had minimal intensity and germ cell degeneration increased. Conclusions: $\mathrm{C} \times 43$ might intermediate a short and transient stimulatory effect of T3 on seminiferous tubule maturation that disappeared together with exposure to the toxic effect of a continuously high level of the hormone.

Key words: Cx43, Sertoli cells, germ cells, seminiferous tubule maturation.

\section{Introduction}

Connexin 43 (Cx43), also called Gjpla, is the predominant protein located in intercellular plasma-membrane channels that directly connect the cytoplasm of adjacent Sertoli cells, between Sertoli cells and germ cells, and between Leydig cells [1]. They allow the direct exchange of molecules with molecular mass up to $1 \mathrm{kDa}$. Such intercellular communication plays an essential role in many physiological processes including cell synchronization proliferation, differentiation, apoptosis and metabolic coordination of avascular organs [2, 3]. In mature rats, the strongest $C \times 43$ expression

\section{Corresponding author:} Jolanta Slowikowska-Hilczer $\mathrm{MD}, \mathrm{PhD}$

Department of Reproductive Endocrinology Chair of Andrology and Reproductive Endocrinology Medical University of Lodz 5 Sterlinga Str. 91-425 Lodz, Poland Phone/fax: +48 426330705 E-mail: jolanta.slowikowska-hilczer @umed.lodz.pl 
appears in stages I-VIII of the seminiferous epithelium cycle $[4,5]$. In mice with mosaic mutation and partial deletion of the long arm of the $Y$ chromosome, severe spermatogenic impairment is associated with the loss of $\mathrm{Cx} 43$ immunoreactivity. This suggests that $\mathrm{Cx} 43$-based gap junctions play a role in spermatogenesis [6].

Thyroid hormone shortens the time when Sertoli cells divide postnatally. Neonatal hyperthyroidism decreased adult Sertoli cell populations by premature cessation of their proliferation and stimulated their maturation events such as seminiferous tubule canalisation [7-9]. Several recent studies have demonstrated that the inhibitory effect of T3 on Sertoli cell proliferation is associated with increased levels of Cx43 in postnatal testis [10-12]. Mice congenitally lacking Cx43 develop seminiferous tubules containing fewer germ cells and a vacuous lumen in the postnatal period of life [13].

A natural decrease in the incidence of $\mathrm{C} \times 43$ positive seminiferous tubule cross-sections from about $90 \%$ to $60 \%$ was reported to occur during progression of normal tubule maturation in rodents $[4,14]$. This decline may correspond to a natural decline in the expression of thyroid hormone receptor (TR) in rat Sertoli cells. TR expression is high after birth, gradually decreases by between pnd 15 and 20 and is minimal thereafter [15-17]. Gilleron et al. [10] have suggested that Cx43 might mediate the stimulatory effect of thyroid hormone on Sertoli cell maturation in vitro.

The influence of $\mathrm{T} 3$ systemic administration on Cx43 expression during seminiferous tubule maturation has not been investigated yet and is the subject of the present study.

\section{Material and methods}

\section{Animals and treatments}

Pregnant Wistar rats were obtained from the Department of Animal Facilities, Medical University of Lodz (Poland). On the day of birth (day 1) the litters were designated at random to treatment and control groups. Each group, containing 5 animals, was kept in a separate cage together with one lactating female. Animals were maintained at a stable temperature $\left(22^{\circ} \mathrm{C}\right)$ and diurnal light-dark cycles (12L : 12D) with free access to food and water. The experiment was performed in accordance with Polish legal requirements, under the license given by the Commission of Animal Ethics at the Medical University of Lodz, Poland.

Male pups received daily subcutaneous injections of $100 \mu \mathrm{g}$ T3/kg body weight (b.w.) (SigmaAldrich, St. Louis, USA), dissolved in $0.025 \mathrm{~N} \mathrm{NaOH}$ in saline solution [7, 17]. Injections of T3 took place from pnd 1 to 5 followed by daily injections with solvent until pnd 15 (transient T3 administration -
tT3), or pups were continuously injected with T3 from pnd 1 until 15 (continuous T3 administration - cT3). Animals were autopsied on pnd 16. The control group received daily subcutaneous injections of $0.025 \mathrm{~N} \mathrm{NaOH}$ in saline solution at the same volume $(0.1 \mathrm{ml})$ until pnd 15 . To estimate the degree of maturational changes in the seminiferous epithelium in experimental rats, six adult untreated rats were euthanized on pnd 50 and evaluated.

Before autopsy, rats were anaesthetized with Thiopental (Sandoz GmbH, Kundl, Austria) and Fentanyl WZF (Polfa, Pabianice, Poland) and weighed. Blood samples were taken by cardiac puncture. Paired testes weight was measured at autopsy. The relative paired testes weight was calculated as paired testes weight/10 g b.w. The right testis of each rat was fixed in Bouin's fluid and embedded in paraffin.

\section{Hormone assays}

After centrifugation of the blood, the serum was collected, frozen and stored at $-20^{\circ} \mathrm{C}$ until assayed. All samples were measured in the same assay. Free iodothyronine 3 (fT3) concentration was determined by microparticle enzyme immunoassay (MEIA) (Abbott Diagnostics, Illinois, USA) with a sensitivity of $1.0 \mathrm{pg} / \mathrm{ml}$. Rat follicle-stimulating hormone ( $\mathrm{rFSH})$ concentrations were determined by double antibody radioimmunoassay (Ortho-Clinical Diagnostics, Amersham, UK) with a sensitivity of $1.0 \mathrm{ng} / \mathrm{ml}$. Concentrations of testosterone and oestradiol were determined by competitive immunoassay technique (Ortho-Clinical Diagnostics, Amersham, UK). The sensitivities were $0.03 \mathrm{nmol} / \mathrm{l}$ for testosterone and $10.0 \mathrm{pmol} / \mathrm{l}$ for oestradiol.

\section{Seminiferous tubule morphometry}

Sections $4 \mu \mathrm{m}$ thick from equatorially cut testes were stained with haematoxylin (Bio-Optica, Milano, Italy) and eosin (Serva, Heidelberg, Germany). The diameters of 100 randomly selected tubular crosssections of seminiferous tubules for each animal were analysed using image analysis software LXAND v3.60HM (Logitech, Lodz, Poland).

The total length of the seminiferous tubule $(L)$ was calculated using the transformed standard equation for a tube model $\left(L=V / \pi r^{2}\right)$ [18], where $V$ was seminiferous tubule volume and $r$ radius of the tubule. The first step was to evaluate the volume density $(V v)$ of the seminiferous tubules by point counting [19]. Ten randomly selected sections of the testis of each animal were examined using image analysis software which superimposed a square lattice containing 441 intersections on the microscopic image. The number of intersections on the examined structure over the entire tissue section was counted by a predetermined and systematic movement of sections across the grid without overlap. $v v$ was 
obtained by dividing the sum of the points falling on the tubular cross-sections by the total number of points over the tissue. The results were expressed as a percentage. The volume of the seminiferous tubules $(V)$ was subsequently determined by multiplying $V v$ by fresh testis volume $(V T): V=V v \times V T$. The specific gravity of testicular tissue is about 1.0, so the values obtained for testicular weight were taken as being equivalent to fresh testicular volume.

\section{Germ cell degeneration}

Toluidine blue (Bio-Optica, Milano, Italy) staining was performed for the identification of germ cell degeneration in paraffin sections [20,21]. Germ cell degeneration was expressed as a percentage of tubular cross-sections containing degenerating cells, identified as having strongly condensed, darkly stained nuclei in toluidine-blue-stained sections. 100 tubular cross-sections per animal were scored. All counts were performed at $1000 \times$ magnification in the light microscope (Nikon, Eclipse E600, Tokyo, Japan).

\section{Immunohistochemical staining for Cx43 expression}

Testes sections ( $4 \mu \mathrm{m}$ thick) were placed onto slides coated with $0.1 \%$ poly-L-lysine solution (Sigma-Aldrich, St. Louis, USA), then dewaxed and dehydrated in xylene and graded ethanols, and rehydrated. To optimize immunohistochemical staining, the samples were exposed to an antigen retrieval procedure by microwaving ( $800 \mathrm{~W}$ ) tissue sections in $0.01 \mathrm{M}$ citrate buffer ( $\mathrm{pH}$ 6.0). Endogenous peroxidase activity was blocked by incubating sections in $0.03 \% \mathrm{H}_{2} \mathrm{O}_{2}$. A mouse monoclonal antibody raised against amino acids 241-254 within the cytoplasmic domain of Cx43 of rat origin (Santa Cruz Biotechnology Inc., Santa Cruz, USA) was used. Sections were incubated with the primary antibody $(1: 25)$ for $30 \mathrm{~min}$. To reduce background staining, the primary antibody was diluted in a diluent with background reducing components (Dako, Glostrup, Denmark). A commercially available EnVision system-HRP kit (Dako, Glostrup, Denmark), based on a horseradish peroxidase labelled polymer, was used as a secondary reagent. After each step, the sections were rinsed and incubated twice for $5 \mathrm{~min}$ in Tris Buffered Saline with Tween-20 pH 7.4 (Sigma-Aldrich, St. Louis, USA). The colour reaction was developed using 3,3'-diaminobenzidine chromogen solution, which resulted in a brown-coloured precipitate at the antigen site. Then the sections were counterstained with Mayer's haematoxylin (BioOptica, Milano, Italy). For the negative control the sections were incubated with non-immune serum instead of the primary antibody.

Considering that the seminiferous epithelium cycle is already established from pnd 15 in rats [22], the evaluation of Cx43 expression was performed in tubular cross-sections containing the same germ cell associations. Based on the abbreviated classification described by Russell et al. [23, 24] for immature rats with a paucity of spermatids, two cell associations were selected. Both contain type A spermatogonia and single pachytene spermatocytes but association 1 contains type B spermatogonia, i.e. it represents stages V/VI of the adult seminiferous epithelium cycle. In turn, association 2 contains preleptotene spermatocytes, i.e. it represents stages VII/VIII. Localization of Cx43 antigen was estimated qualitatively in the light microscope (Nikon, Eclipse E600, Tokyo, Japan) at 1000× magnification. One hundred tubule cross-sections with equal proportions of both associations were estimated qualitatively. The percentages of seminal tubules revealing a positive immunohistochemical reaction for the presence of $\mathrm{Cx} 43$ in each rat were calculated.

\section{Statistical analysis}

Distribution of the data was analysed using the Shapiro-Wilk test. The parametric data were presented as mean \pm standard deviation and were analysed using one-way ANOVA followed by the least significant differences (LSD) as a post hoc test. Differences were considered significant at $p<0.05$.

\section{Results}

\section{Hormone levels}

In the control group, the fT3 serum level was 2.01 $\pm 0.7 \mathrm{pg} / \mathrm{ml}$, and was 2.6 times higher in tT3 (5.3 \pm 2.7 , $p<0.05)$, and 11.9 times higher in CT3 (23.9 \pm 2.7 $\mathrm{pg} / \mathrm{ml}, p<0.001)$. Serum $\mathrm{rFSH}$ in the control group was $3.3 \pm 1.4 \mathrm{ng} / \mathrm{ml}$ and did not differ significantly in tT3 $(5.7 \pm 4.9)$ or in cT3 $(6.7 \pm 4.5)$. The serum level of testosterone was $0.9 \pm 0.2 \mathrm{nmol} / \mathrm{l}$ in the control group and did not differ either in tT3 $(1.0 \pm 0.2)$ or in CT3 $(1.1 \pm 0.5)$. The serum level of oestradiol was $249.5 \pm 142.3 \mathrm{pmol} / \mathrm{l}$ in the control and did not differ either in tT3 $(377.6 \pm 133.1)$ or in CT3 $(245.9 \pm 74.2)$.

\section{Body and testes weights}

Table I shows that body weight did not change after tT3 treatment but was decreased by $11.7 \%$ after cT3 when compared with the control group. Relative paired testes weight was $34.7 \pm 6.2 \mathrm{mg}$ in the control group, increased by $27.9 \%$ after tT3 and did not change after cT3.

\section{Cx43 expression, seminiferous tubule morphometry and germ cell degeneration}

In the control group, most of the tubules revealed intense, positive staining for $\mathrm{Cx} 43$. The staining was located in the apical adluminal part of the seminiferous epithelium and the tubule lumen was 
Table I. Body and relative testes weights in rats receiving vehicle (Control) or triiodothyronine (T3) in transient or continuous experiments

\begin{tabular}{|lccc|}
\hline Parameter & Control $(n=5)$ & Transient T3 $(n=5)$ & Continuous T3 $(n=5)$ \\
\hline Body weight $[\mathrm{g}]$ & $29.3 \pm 1.45$ & $31.5 \pm 2.49$ & $25.9 \pm 1.94^{\mathrm{a}}$ \\
\hline Relative testes weight $[\mathrm{mg}]$ & $34.7 \pm 6.24$ & $44.4 \pm 3.70^{\mathrm{b}}$ & $33.2 \pm 2.55$ \\
\hline
\end{tabular}

$n$-number of animals, ${ }^{a} p<0.01,{ }^{b} p<0.05$ ANOVA, least significant differences (LSD) as a post hoc test for experimental vs. control group

not present yet. Cx43 was expressed in the cytoplasm of Sertoli cells, evidenced by the columnar distribution of staining, a pattern typical for Sertoli cells (Figures $1 \mathrm{~A}, 1 \mathrm{~B}$ ).

After tT3 treatment, tubule diameter increased, and $\mathrm{Cx} 43$ immunostaining disappeared from the adluminal region of Sertoli cell cytoplasm and was localized peripherally in Sertoli cell cytoplasm close to the layer of Sertoli cell nuclei. Most tubules developed a lumen (Figures 1 C, 1 D).

After cT3 treatment, the seminiferous tubule lumen was the widest one with a distinctly outlined border (Lu) which, together with the short length

A

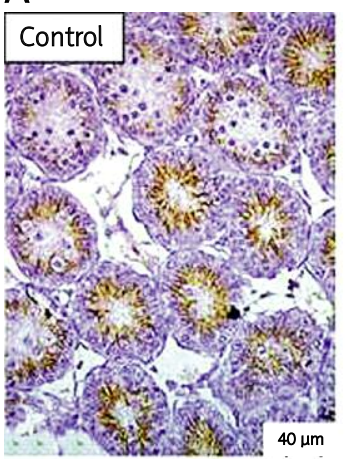

C

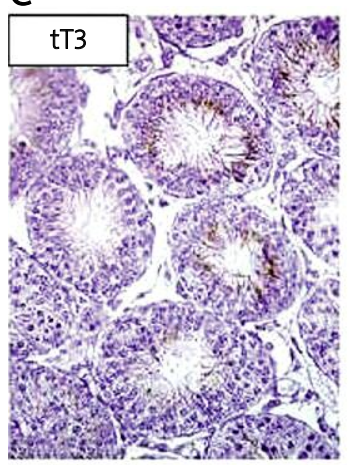

$\mathrm{E}$

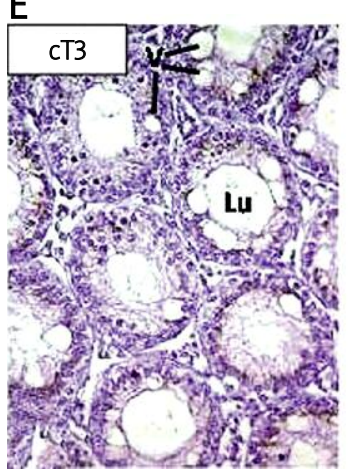

B

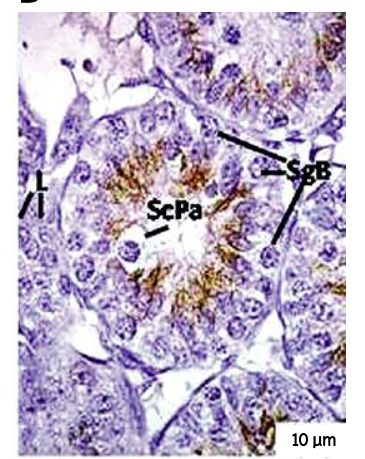

D

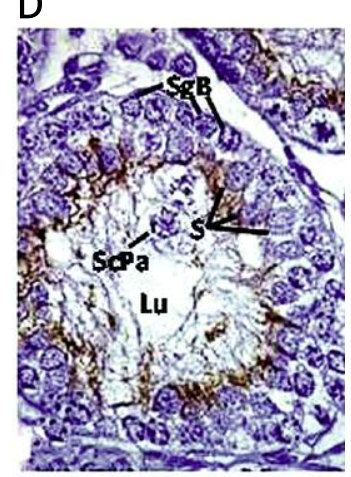

$\mathrm{F}$

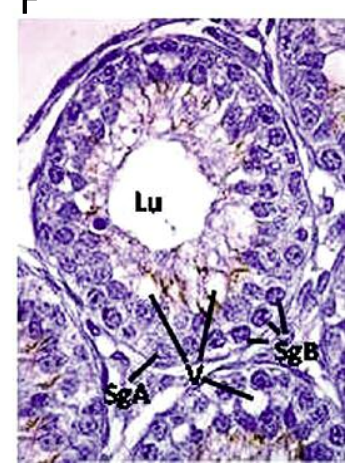

of seminiferous tubule growth, was suggestive of seminiferous tubule distention. The Sertoli cell cytoplasm became vacuolated. As after tT3 also after CT3, Cx43 immunostaining was absent in the adluminal part of the seminiferous epithelium, but had minimal or almost undetectable expression (Figures $1 \mathrm{E}, 1 \mathrm{~F}$ ). In 50-day-old adult rats, the incidence of Cx43 positive tubules was $28.9 \pm 2.5 \%$ and $C \times 43$ immunostaining was located superior to the layer of spermatogonia (Figure 2).

Seminiferous tubule diameter increased after both $\mathrm{tT} 3$ and CT3 (Figure $3 \mathrm{~A}$ ), while the length of seminiferous tubules was reduced after cT3 (Figure $3 \mathrm{~B}$ ). The incidence of tubules containing degenerating germ cells was $19.8 \pm 4.7 \%$ in the control group, similar to tT3 $(21.3 \pm 9.0 \%)$, but increased to $37.6 \pm 5.1 \%$ in cT3 (1.9-fold of control, $p<0.01$ ) (Figure 3 C).

The incidence of tubular cross-sections positive for $\mathrm{Cx} 43$ was $86.2 \pm 8.6 \%$ in the control group and was reduced to $46.3 \pm 9.8 \%$ in tT3 $(46 \%$ less than control, $p<0.001)$ and to $45.8 \pm 8.1 \%$ in CT3 $(47 \%$ less than control, $p<0.001$ ) (Figure $3 \mathrm{D}$ ).

\section{Discussion}

Transient administration of T3 increased 2.6-fold serum fT3 level, despite discontinuation of the treatment 11 days earlier, while continuous treatment increased serum fT3 12 -fold. T3 is prevalent within tissues, has high potency, rapid effects and rapid turnover. Panno et al. [25] found that in immature rats serum level of total $\mathrm{T} 3$ did not increase on the day that followed 7-day intraperitoneal daily administration of T3. This discrepancy may arise from the different route of administration of T3 (here

Figure 1. Representative photomicrographs of seminiferous tubule cross-sections in germ cell association 1 , immunostained for connexin 43 (Cx43) (brown colour) in rats from the control group (Control: A, B), rats treated transiently with T3 (tT3: C, D) or continuously (CT3: E, F). Note that in Control, all seminiferous tubule cross-sections are Cx43 positive, while in tT3 and CT3 Cx43-positive tubules are less frequently seen (C, E). In Control, Cx43 expression is intense and abundant, localized in the adluminal part of Sertoli cell cytoplasm (A, B), whereas in tT3 Cx43 immunostaining is localized more peripherally (C, D). In CT3 an enlarged tubule lumen $(\mathrm{Lu})$ is associated with vacuolation (V) of Sertoli cell cytoplasm (E), and Cx43 immunostaining almost disappeared (F)

$S$ - Sertoli cell, SgA - type A spermatogonia, SgB - type B spermatogonia, SCPA - pachytene spermatocytes (Bar $=40 \mu \mathrm{m}$ in $A$, $C, E$ and bar $=10 \mu \mathrm{m}$ in $B, D, F)$ 
A

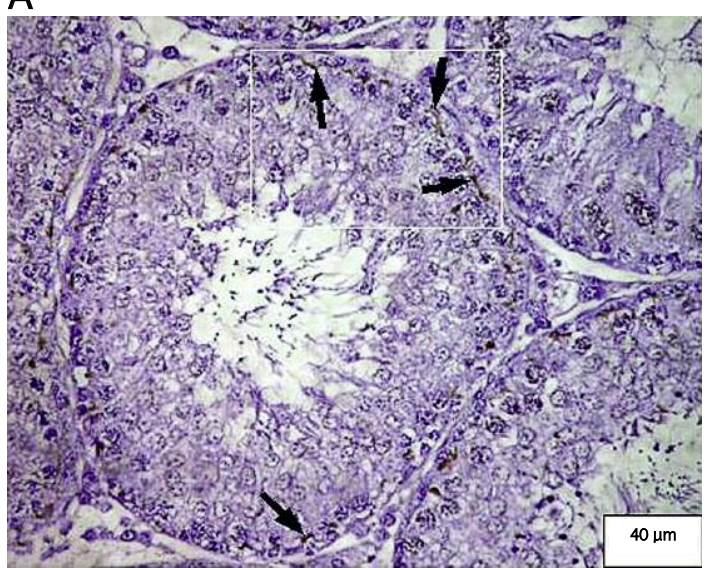

B

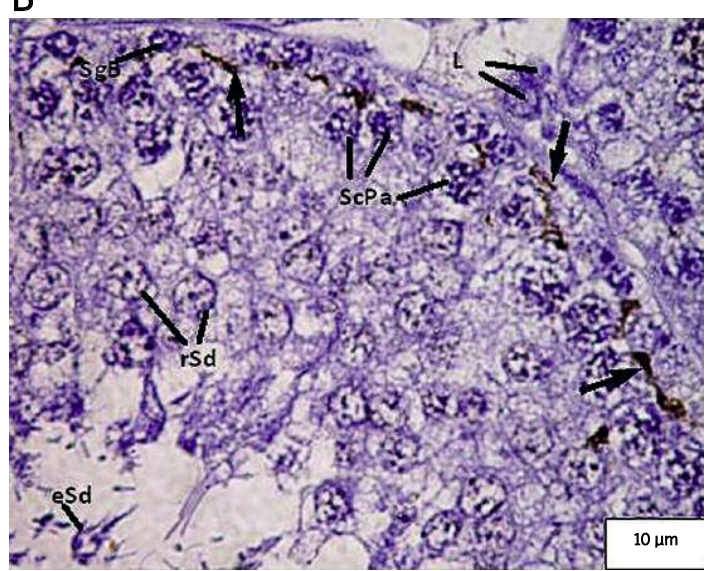

Figure 2. Representative photomicrographs of seminiferous tubule cross-section immunostained for connexin 43 (CX43) (brown colour - arrows) in 50-day-old rats in stage VI of the seminiferous epithelium cycle. The section of the seminiferous tubule marked by a white rectangle in Figure $\mathrm{A}$ is magnified in Figure 2

$S g B$ - type B spermatogonia, ScPa-pachytene spermatocytes, $r S d$ - round spermatids, eSd-elongate spermatids, $L-L e y d i g$ cells (Bar $=40 \mu \mathrm{m}$ in $A$ and bar $=10 \mu \mathrm{m}$ in $B$ )

A

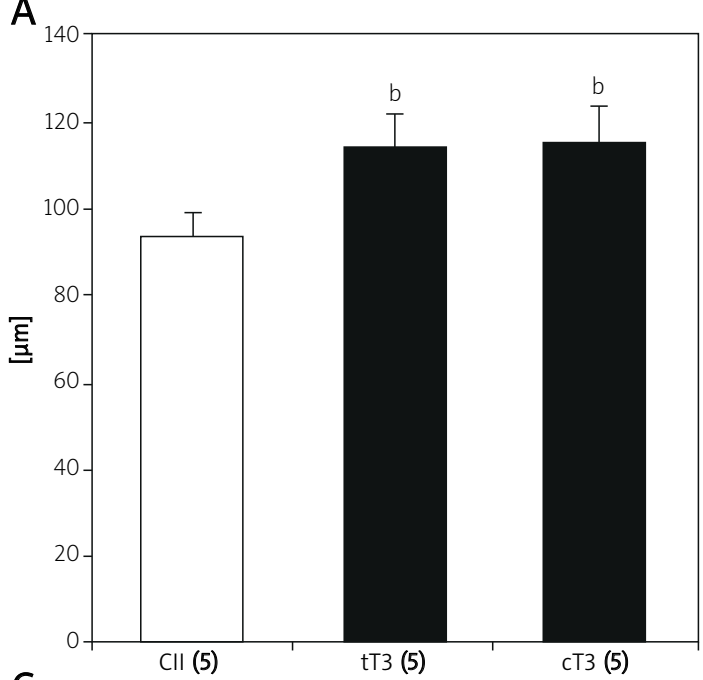

C

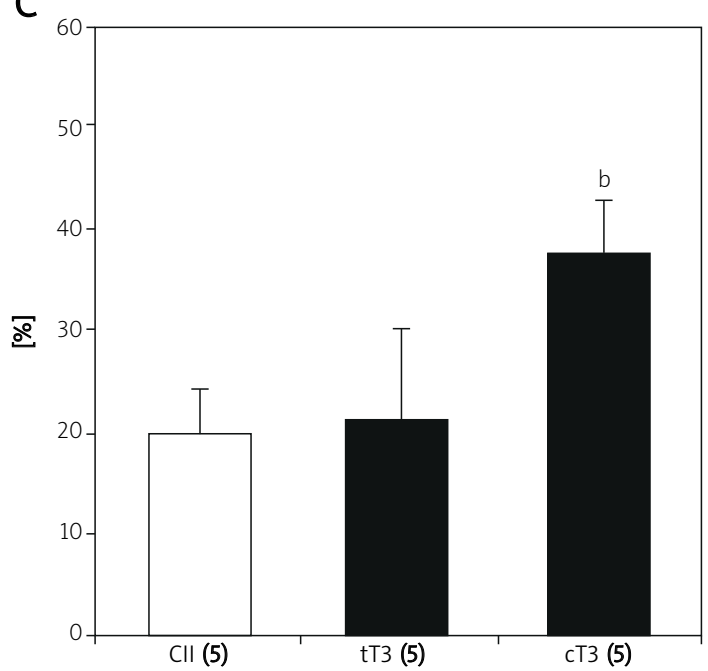

B

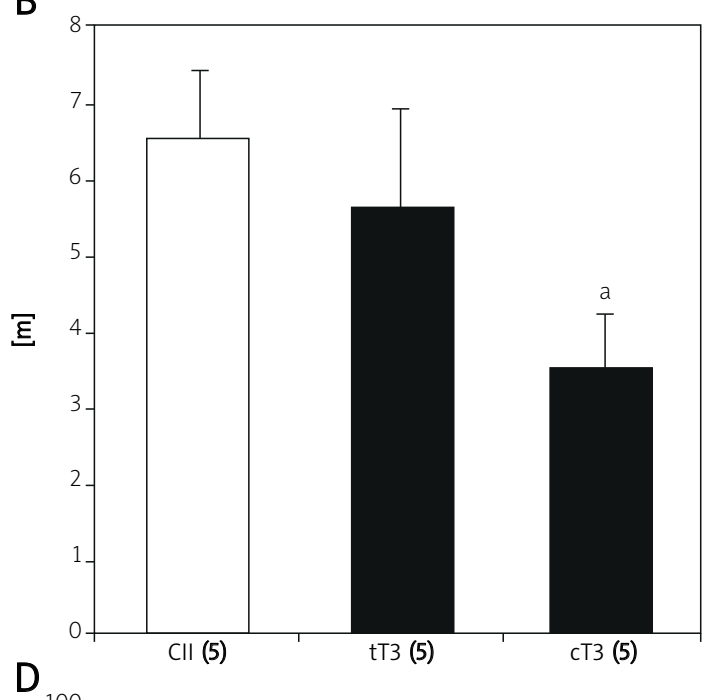

D

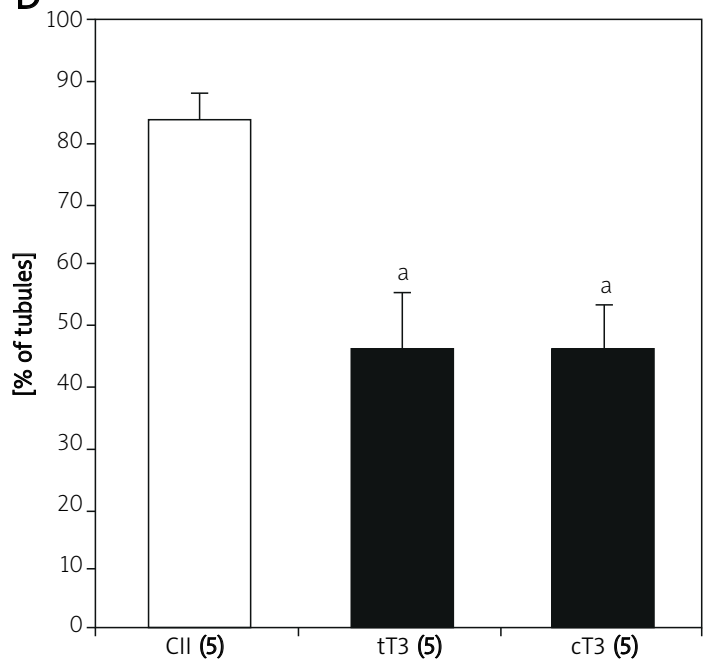

Figure 3. The influence of triiodothyronine after transient (tT3) or continuous (CT3) administration on seminiferous tubule diameter (A), total length (B), the incidence of tubules containing degenerating germ cells (C), and the incidence of tubules positive for $C \times 43$ (D) (mean \pm SD)

$C$ - control group; Analysis of variance (ANOVA); ${ }^{a} p<0.001,{ }^{b} p<0.01$; number of animals in parenthesis 
subcutaneous) and the higher dose applied here $(100 \mu \mathrm{g} / \mathrm{kg}$ b.w. instead of $30 \mu \mathrm{g} / \mathrm{kg}$ as applied previously). Indeed, it has been reported that in a hypothyroid woman, erroneous oral intake of an excessive dose of T3 ( $5 \mathrm{mg}$ of T3 every $8 \mathrm{~h}$ ) for 9 days resulted in 397 times higher than normal serum level of total T3 after the treatment. The T3 level was normalized $200 \mathrm{~h}$ (8.3 days) after the intake of the last dose, and clinical manifestation of toxic effects still lasted 3 days more [26].

While transient treatment increased testes weight and seminiferous tubule diameter, continuous treatment decreased tubule length and increased germ cell degeneration. A decrease in body weight indicated a thyrotoxic effect of high T3 level. Follicle-stimulating hormone (FSH) is responsible for seminiferous tubule growth [27], and it was previously found that in pubertal ram lambs, T3 administration decreased serum levels of FSH [28]. In our study, FSH level did not differ from earlier reports incorporating a rat model [7]. Neither of the treatments influenced serum levels of testosterone or oestradiol, indicating a direct hormonal effect of T3.

We observed that in untreated 16-day-old rats, $86 \%$ of seminiferous tubule cross-sections were Cx43-positive. A similar figure has been reported to occur in older rats (at pnd 22-30) where indirect immunofluorescence techniques in frozen sections of the testes were used [4]. Together with an increase in the seminiferous tubule diameter by $\mathrm{T} 3$ administration, the incidence of $\mathrm{C} \times 43$ positive tubules declined from about $90 \%$ to less than $50 \%$ and only $29 \%$ of tubule cross-sections were Cx43 positive in 50-day-old untreated mature rats. A decrease in the incidence of $\mathrm{Cx} 43$-positive tubule crosssection from about $90 \%$ to $60 \%$ was reported to occur during progression of seminiferous tubule maturation in normal rats $[4,14]$. Hence our data suggest that maturational changes in Cx43 expression in seminiferous tubules may depend on thyroid hormone action.

We also found that while in the untreated 16-dayold rats Cx43 immunostaining had an apical, adluminal localization in the seminiferous epithelium, it shifted into the periphery after T3 administration. In normal rats, expression of $\mathrm{Cx} 43$ undergoes natural dislocation from the apical to the basal part of Sertoli cell cytoplasm from pnd 22 onward [4, 29]. A delay of the natural dislocation of Cx43 expression within the cytoplasm of maturating Sertoli cells has been observed in hypothyroid neonatal rats [29]. This suggests that thyroid hormone may be responsible for maturational shift in Cx43 expression localization within the seminiferous epithelium. Pelletier [30] proposed that Cx43 may play a role in the formation at puberty of the blood-testis barrier, a structure that develops in the basal part of Sertoli cell cytoplasm.
In turn, continuous T3 treatment with a high final level of T3 caused immunostaining for $\mathrm{C} \times 43$ to be weaker (or almost undetectable) than that found after transient treatment. Seminiferous tubule growth was inhibited, tubules distended, the Sertoli cell cytoplasm had become vacuolated and germ cell degeneration increased, all suggesting a toxic effect of T3. A decrease in seminiferous tubule growth was presumably due to the inhibition of Sertoli cell proliferation, as previously observed after T3 administration in a similar experiment [7]. The vacuolation of Sertoli cell cytoplasm is indicative of a breakdown in Sertoli-germ cell junctions [31]. Tribulova et al. [32] demonstrated that although T3 increased the expression of $\mathrm{C} \times 43$ in heart myocytes in vitro, the exposure to higher concentrations of T3 caused disintegration of sarcomeric $\beta$-actin in myocytes, suggesting "overdosage" of T3. T3-induced cardiac thyrotoxicosis was shown to be associated with increased proteolysis in heart myocytes [33]. Thyrotoxicosis-induced increased proteolysis might be a cause of the observed decline in Cx43 expression connected with regressive changes within the seminiferous epithelium.

In conclusion, maturational changes in Cx43 expression within the seminiferous epithelium might arise from the short and transient stimulatory influence of thyroid hormone on testes maturation. In turn, reduced $\mathrm{Cx} 43$ expression was associated with regressive changes in seminiferous tubules, which might suggest deprivation of $\mathrm{Cx} 43$ activity by the toxic effects of continuously high levels of $\mathrm{T} 3$.

\section{Acknowledgments}

This work was supported by Medical University of Lodz grant nos. 503-1089-2/3 and 502-11-711, 502-11-427.

\section{References}

1. Tan IP, Roy C, Saez JC, et al. Regulated assembly of connexin33 and connexin43 into rat Sertoli cell gap junctions. Biol Reprod 1996; 54: 1300-10.

2. Vinken M, Vanhaecke T, Papeleu P, et al. Connexins and their channels in cell growth and cell death. Cell Signal 2006; 18: 592-600.

3. Mehta PP. Introduction: a tribute to cell-to-cell channels. J Membr Biol 2007; 217: 5-12.

4. Risley MS, Tan IP, Roy C, Saez JC. Cell-, age- and stage-dependent distribution of connexin43 gap junctions in testes. J Cell Sci 1992; 103: 81-96.

5. Batias C, Siffroi JP, Fenichel P, Pointis G, Segretain D. Connexin43 gene expression and regulation in the rodent seminiferous epithelium. J Histochem Cytochem 2000; 48: 793805.

6. Kotula-Balak M, Hejmej A, Sadowska J, Bilinska B. Connexin 43 expression in human and mouse testes with impaired spermatogenesis. Eur J Histochem 2007; 51: 261-8.

7. van Haaster LH, de Jong FH, Docter R, de Rooij DG. High neonatal triiodothyronine levels reduce the period of Sertoli cell proliferation and accelerate tubular lumen forma- 
tion in the rat testis, and increase serum inhibin levels. Endocrinology 1993; 133: 755-60.

8. Cooke PS, Zhao YD, Bunick D. Triiodothyronine inhibits proliferation and stimulates differentiation of cultured neonatal Sertoli cells: possible mechanism for increased adult testis weight and sperm production induced by neonatal goitrogen treatment. Biol Reprod 1994; 51: 1000-5.

9. Palmero S, Prati M, Bolla F, Fugassa E. Tri-iodothyronine directly affects rat Sertoli cell proliferation and differentiation. J Endocrinol 1995; 145: 355-62.

10. Gilleron J, Nebout M, Scarabelli L, et al. A potential novel mechanism involving connexin 43 gap junction for control of sertoli cell proliferation by thyroid hormones. I Cell Physiol 2006; 209: 153-61.

11. Brehm R, Zeiler M, Ruttinger C, et al. A sertoli cell-specific knockout of connexin43 prevents initiation of spermatogenesis. Am J Pathol 2007; 171: 19-31.

12. Sridharan S, Simon L, Meling DD, et al. Proliferation of adult sertoli cells following conditional knockout of the Gap junctional protein GJA1 (connexin 43) in mice. Biol Reprod 2007; 76: 804-12.

13. Roscoe WA, Barr KJ, Mhawi AA, Pomerantz DK, Kidder GM. Failure of spermatogenesis in mice lacking connexin43. Biol Reprod 2001; 65: 829-38.

14. Bravo-Moreno JF, Diaz-Sanchez V, Montoya-Flores JG, et al. Expression of connexin43 in mouse Leydig, Sertoli, and germinal cells at different stages of postnatal development. Anat Rec 2001; 264: 13-24.

15. Jannini EA, Olivieri M, Francavilla $S$, et al. Ontogenesis of the nuclear 3,5,3'-triiodothyronine receptor in the rat testis. Endocrinology 1990; 126: 2521-6.

16. Canale D, Agostini M, Giorgilli G, et al. Thyroid hormone receptors in neonatal, prepubertal, and adult rat testis. J Androl 2001; 22: 284-8.

17. Holsberger DR, Kiesewetter SE, Cooke PS. Regulation of neonatal Sertoli cell development by thyroid hormone receptor alpha1. Biol Reprod 2005; 73: 396-403.

18. Wing TY, Christensen AK. Morphometric studies on rat seminiferous tubules. Am J Anat 1982; 165: 13-25.

19. Mori H, Christensen AK. Morphometric analysis of Leydig cells in the normal rat testis. J Cell Biol 1980; 84: 340-54.

20. Jannini EA, Ulisse S, Piersanti D, et al. Early thyroid hor mone treatment in rats increases testis size and germ cell number. Endocrinology 1993; 132: 2726-8.

21. Russell LD, Clermont Y. Degeneration of germ cells in normal, hypophysectomized and hormone treated hypophy sectomized rats. Anatomical Record 1977; 187: 347-66.

22. Clermont Y, Perey B. Quantitative study of the cell population of the seminiferous tubules in immature rats. Am J Anat 1957; 100: 241-67.

23. Russell L, Frank B. Characterization of rat spermatocytes after plastic embedding. Arch Andrology 1978; 1: 5-18.

24. Russell LD, Alger LE, Nequin LG. Hormonal control of pubertal spermatogenesis. Endocrinology 1987; 120: 1615-32.

25. Panno ML, Salerno M, Lanzino M, et al. Follow-up study on the effects of thyroid hormone administration on androgen metabolism of peripubertal rat Sertoli cells. Eur J Endocrinol 1995; 132: 236-41.

26. Botella de Maglia J, Compte Torrero L, Rivas Sanchez A, Perez Pastor JL. Triiodothyronine intoxication. A clinical and phamacokinetic study. Anales de Medicina Interna 2003; 20: 627-9.

27. Kula K, Walczak-Jedrzejowska R, Slowikowska-Hilczer J, Oszukowska E. Estradiol enhances the stimulatory effect of FSH on testicular maturation and contributes to precocious initiation of spermatogenesis. Mol Cell Endocrinol 2001; 178: 89-97.
28. Fallah-Rad AH, Connor ML, Del Vecchio RP. Effect of transient early hyperthyroidism on onset of puberty in Suffolk ram lambs. Reproduction 2001; 121: 639-46.

29. St-Pierre N, Dufresne J, Rooney AA, Cyr DG. Neonatal hypothyroidism alters the localization of gap junctional protein connexin 43 in the testis and messenger RNA levels in the epididymis of the rat. Biol Reprod 2003; 68: 1232-40.

30. Pelletier RM. The distribution of connexin 43 is associated with the germ cell differentiation and with the modulation of the Sertoli cell junctional barrier in continual (guinea pig) and seasonal breeders' (mink) testes. J Androl 1995; 16: 400-9.

31. Russell L, Etilin R, Shina-Hikim A, Clegg E. Histological and histopathological evaluation of the testis. 1st. Cache River Press Clearwater 1990.

32. Tribulova N, Shneyvays V, Mamedova LK, et al. Enhanced connexin-43 and alpha-sarcomeric actin expression in cultured heart myocytes exposed to triiodo-L-thyronine. J Mol Histol 2004; 35: 463-70.

33. Parmacek MS, Magid NM, Lesch M, Decker RS, Samarel AM. Cardiac protein synthesis and degradation during thyroxine-induced left ventricular hypertrophy. Am J Physiol 1986; 251: C727-36. 